\title{
Relationship between $T$ lymphocyte subsets and cortisol in systemic lupus erythematosus
}

\section{Shah $\mathbf{D}^{1}$, Kiran $\mathbf{R}^{1}$, Wanchu $\mathbf{A}^{2}$, Bhatnagar $\mathbf{A}^{1}$}

Department of Biochemistry ${ }^{1}$, Basic Medical Science Block, Panjab University, Chandigarh, India, Department of Internal Medicine ${ }^{2}$, Postgraduate Institute of Medical Education and Research, Chandigarh, India.

\begin{abstract}
Background: Systemic Lupus Erythematosus (SLE) is a complex chronic immunological disease characterized by increased B cell activity and altered $\mathrm{T}$ cell function.

Objective: To investigate relationship between T lymphocyte subsets and cortisol with the disease activity of systemic lupus erythematosus patients in North India.

Materials and methods: The percentage of $\mathrm{CD}^{+}$and $\mathrm{CD}^{+} \mathrm{T}$ cells in the lymphocyte of SLE patients and healthy controls were determined by flow cytometry. Serum cortisol of SLE patients and healthy controls was determined by enzyme-linked immunosorbent assay (ELISA).

Results: A significant decrease in the percentage of $\mathrm{CD} 4^{+} \mathrm{T}$ cells and increase in the percentage of CD $8^{+} \mathrm{T}$ cells were found in patients with SLE compared to the healthy controls. Decrease in the ratio of $\mathrm{CD}^{+} / \mathrm{CD}^{+} \mathrm{T}$ cell and low level of serum cortisol were found in the patients with SLE. The ratio of $\mathrm{CD}^{+} / \mathrm{CD}^{+} \mathrm{T}$ cell was inversely correlated with systemic lupus erythematosus disease activity index (SLEDAI) score and erythrocyte sedimentation rate (ESR). A positive correlation was observed between $\mathrm{CD} 8^{+} \mathrm{T}$ cells and SLEDAI score. Furthermore, $\mathrm{CD} 8^{+} \mathrm{T}$ cells were positively correlated with ESR in the patients with SLE.
\end{abstract}

Conclusion: The results showed that low level of cortisol and high percentage of $\mathrm{CD}^{+} \mathrm{T}$ cells in the lymphocytes could be actively involved in the pathogenesis of SLE.

Key words: $\mathrm{CD}^{+} / \mathrm{CD}^{+} \mathrm{T}$ cell ratio, cortisol, systemic lupus erythematosus, T-cell activation

\begin{abstract}
Oystemic lupus erythematosus (SLE) is a chronic $\checkmark$ inflammatory autoimmune disease of unknown aetiology, characterised by arthritis, cutaneous rash, vasculitis, involvement of central nervous system, renal and cardiopulmonary manifestations ${ }^{1}$. Due to loss of self-tolerance there is persistence of autoreactive B and T lymphocyte in $\mathrm{SLE}^{2}$. This leads to both systemic and organ-specific autoimmunity. The activation of autoreactive $\mathrm{T}$ lymphocytes leads to the abnormalities of $\mathrm{CD}^{+}$and $\mathrm{CD}^{+} \mathrm{T}$ cells, their numbers and also engenders the autoantibody production characteristic of SLE ${ }^{3,4,5}$. Previous studies have found either normal or increased or decreased levels of CD8+ T cells and a decrease in $\mathrm{CD}^{+} \mathrm{T}$ cells, with a consequent decrease of the $\mathrm{CD}^{+} / \mathrm{CD}^{+} \mathrm{T}$ cell ratio in SLE patients ${ }^{5,6,7}$. However, the mechanism of the induction of $\mathrm{CD}^{+} \mathrm{T}$ cell abnormality and its relationship with $\mathrm{CD}^{+} \mathrm{T}$ cell and clinical features of SLE is still not clear. The circulating lymphocyte ratios have been known to be markedly affected by corticosteroids, an anti-inflammatory hormone, in patients with $\mathrm{SLE}^{8}$. The reduced level of cortisol has been found to increase inflammation in the patients with $\mathrm{SLE}^{9}$. However, role of cortisol in relation
\end{abstract}

to the T lymphocytes subsets and pathogenesis of SLE is yet to be investigated.

In the present study, the distribution of $\mathrm{T}$ lymphocytes subset and its correlation with cortisol and disease activity has been evaluated in SLE patients.

\section{Materials and methods}

\section{Subjects}

Patients were selected among individuals attending out-patient Department of Internal Medicine at Postgraduate Institute of Medical Education and Research, Chandigarh, India. The study included 30 patients with SLE (27 females, 3 males) with mean age of $27.50 \pm 7.48$ years and the control group consisted of 30 healthy volunteers ( 27 females, 3 males) with mean age of $26.73 \pm 5.37$ years. SLE was diagnosed

\footnotetext{
Correspondence

Dr. Archana Bhatnagar

Department of Biochemistry, Basic Medical Science Building

Panjab University, Chandigarh-160014 (India)

E-mail: bhatanagar.archana@gmail.com
} 
using the 1982 American Rheumatism Association revised criteria ${ }^{10}$. Disease activity was determined by using SLE Disease Activity Index (SLEDAI) score ${ }^{11}$. The study protocol was approved by the Institute Ethics Committee, Postgraduate Institute of Medical Education and Research, Chandigarh, India and informed consent was obtained from all the patients and controls (healthy subjects). All the patients enrolled in the present study were non-smoker and non-alcoholic.

\section{Blood Samples}

Venous blood samples were obtained from patients and healthy controls. Samples were collected into plain and heparinised vacutainers (Becton Dickinson, USA). Samples from plain vacutainers were left to clot, serum was separated, aliquoted and used for estimation of cortisol. Heparinised blood samples were used for the isolation of peripheral blood mononuclear cells (PBMC) for the determination of percentage of $\mathrm{CD}^{+}$and $\mathrm{CD} 8^{+}$ $\mathrm{T}$ cells.

\section{Determination of $\mathrm{CD}^{+}$and $\mathrm{CD} 8^{+} \mathrm{T}$ cells}

Peripheral blood mononuclear cells (PBMC) were freshly isolated from heparinised venous blood by Ficoll-Hypaque (Sigma-Aldrich, USA) density gradient centrifugation ( $400 \mathrm{x} \mathrm{g}$ ) for 30 minutes. After washing with isotonic phosphate buffered saline solution, cells were enumerated. The cell suspension was adjusted to the concentration of $1 \times 10^{6} / \mathrm{ml}$ in RPMI 1640 (Sigma Aldrich, USA), supplemented with 10\% heatinactivated fetal calf serum (Sigma Aldrich, USA). Twenty microlitres of mouse anti-human anti-CD4FITC (BD Bioscience) and $20 \mu$ l of mouse anti-human anti-CD8-APC (Immunostep, Spain) were added and incubated in the dark at $4^{\circ} \mathrm{C}$ for one hour. After washing twice with PBS, cells were fixed with $1 \%$ paraformaldehyde. Negative controls were performed simultaneously using FITC-labelled mouse anti-human IgG1 mAb (BD Bioscience) and APC-labelled mouse anti-human IgG1 mAb (BD Bioscience). Cells were acquired and analysis was performed on FACS-Calibur (Becton Dickinson, San Jose, CA, USA) using Cell Quest software (TreeStar, San Carlos, CA, USA).

\section{Determination of serum cortisol}

Serum cortisol level was measured by a commercially available enzyme linked immunosorbent assay (ELISA) (Immuno-Technology \& Steroid Lab, India). Assay was performed according to manufacturer's instruction. The sensitivity of the kit was $0.28 \mu \mathrm{g} / \mathrm{dl}$. Briefly, serum samples and standards were incubated in the anti-cortisol antibody coated wells with horse radish peroxidase-cortisol (HRP-cortisol) conjugate. After incubation, the liquid contents of the wells were decanted and the wells were washed with wash buffer to remove the unbound enzyme conjugates. The bound enzyme activity was measured by developing coloured product from colourless substrate $\left(\mathrm{TMB} / \mathrm{H}_{2} \mathrm{O}_{2}\right.$ solution) after incubation at $450 \mathrm{~nm}$. The levels of serum cortisol were determined by comparison with that of standard curve of cortisol.

\section{Statistical analysis}

Statistically significant differences were determined using the Student's paired t-test. Correlation analyses were performed using two-tailed Spearman's rank correlation. Analyses were performed using GraphPad Prism v.5.00.288 for Windows (GraphPad Software, San Diego,CA). $P$ values less than 0.05 were considered significant.

\section{Results}

The study included 30 patients with SLE (27 females, 3 males) with mean age of $27.50 \pm 7.48$ years and the control group consisted of 30 healthy volunteers (27 females, 3 males) with mean age of $26.73 \pm 5.37$ years. Disease activity was determined by using SLE Disease Activity Index (SLEDAI) score (maximum score of $105)^{11}$ : Mild score <10; Moderate score 10-20; Severe score $>20$. Three patients had moderate SLEDAI score while the rest 27 had a SLEDAI score $>20$ indicating severity of SLE in the present study. The mean SLEDAI Score of the patients with SLE were $38.90 \pm 3.31$. The levels of ESR, C3 and C4 were $50.63 \pm 22.25$ (0 -20 $\mathrm{mm} / \mathrm{hr}), 56.93 \pm 18.62(50-120 \mathrm{mg} / \mathrm{dl})$ and $27.39 \pm$ $12.934(20-50 \mathrm{mg} / \mathrm{dl})$ respectively. Out of 16 patients showing low serum levels of C3 and C4, 5 of them had nephritis. The demographic and clinical characteristics of SLE patients and healthy controls are summarized in the Table 1 and Table 2 respectively.

\section{$\mathrm{CD}^{+}$and $\mathrm{CDB}^{+} \mathrm{T}$ cells in PBMC}

The percentage of $\mathrm{T}$ lymphocyte subsets in the PBMC of SLE patients and healthy controls are shown in the Table 3. A significant decrease in the percentage of $\mathrm{CD}^{+}$ $\mathrm{T}$ cells was found in patients with SLE as compared to healthy controls $(P<0.001)$ while an increase in the percentage of $\mathrm{CD}^{+} \mathrm{T}$-cells was found in patients with SLE as compared to healthy controls $(P<0.001)$. Furthermore, a considerable decrease in $\mathrm{CD} 4^{+} / \mathrm{CD} 8^{+} \mathrm{T}$ cells ratio was found in patients with SLE compared to the healthy controls $(P<0.001)$.

\section{Serum cortisol}

To appraise the role of cortisol in the activation of $\mathrm{T}$ cells, the serum cortisol level was determined. A noteworthy decrease in the level of serum cortisol was found in patients with SLE as compared to healthy controls $(P<0.001)$.

\section{Correlation studies}

To evaluate the relation of T cells and low serum cortisol in the pathogenesis of SLE, correlations among $\mathrm{CD}^{+}$, $\mathrm{CD}^{+}$T cells, serum cortisol, C3, C4, ESR and SLEDAI score was studied. As shown in Table 4, negative correlation was observed between $\mathrm{CD}^{+} \mathrm{T}$ cells $(\mathrm{r}=$ - 
$0.3931, P<0.05)($ Fig $2 \mathrm{a})$ and $\mathrm{CD}^{+} / \mathrm{CD}^{+} \mathrm{T}$ cell ratio $(\mathrm{r}$ $=-0.5594, P<0.01)($ Fig $2 \mathrm{c})$ with SLEDAI score in the patient with SLE. Positive correlations was observed between $\mathrm{CD}^{+} \mathrm{T}$ cells and SLEDAI score $(\mathrm{r}=0.4748$, $P<0.01$ ) (Fig $2 \mathrm{~b}$ ) and between $\mathrm{CD}^{+} \mathrm{T}$ cells and ESR $(\mathrm{r}=0.5926, P<0.001)$ (Fig 2e) in patients with SLE. A negative correlation between $\mathrm{CD}^{+} \mathrm{T}$ cells and $\mathrm{C} 4(\mathrm{r}$ $=-0.3631, P<0.05)$ (Fig 2d) was found to exist. The $\mathrm{CD}^{+} / \mathrm{CD}^{+} \mathrm{T}$ cell ratio showed a negative correction with ESR ( $\mathrm{r}=-0.4687, P<0.01)$ (Fig 2f).

Table 1: Demographic characteristics of patients with systemic lupus erythematosus (SLE) and controls

\begin{tabular}{|l|c|c|}
\hline & SLE patients & Controls \\
\hline Number $(\mathrm{n})$ & 30 & 30 \\
\hline Female/male & $27 / 3$ & $27 / 3$ \\
\hline Age $(\mathrm{yrs})$ & $27.5 \pm 7.48$ & NA \\
\hline Duration of disease & $2.17 \pm 1.60$ & NA \\
\hline ESR $(\mathrm{mm} / \mathrm{hr})$ & $50.63 \pm 22.25$ & NA \\
\hline C3 $(\mathrm{mg} / \mathrm{dl})$ & $56.93 \pm 18.62$ & NA \\
\hline C4 $(\mathrm{mg} / \mathrm{dl})$ & $27.39 \pm 12.934$ & NA \\
\hline SLEDAI Score & $38.90 \pm 3.31$ & \\
\hline
\end{tabular}

Values are expressed as Mean $\pm \mathrm{SD}, \mathrm{NA}$ : not applicable

Table 2: Symptoms in patients with SLE

\begin{tabular}{|l|c|c|}
\hline Symptoms & Patients $(\mathbf{n}=\mathbf{3 0})$ & \% \\
\hline Arthralgia & 26 & 86.66 \\
\hline Oral ulcers & 16 & 53.33 \\
\hline Skin lesion & 22 & 73.33 \\
\hline Phtosensitivity & 17 & 56.66 \\
\hline Lympadenopathy & 4 & 13.13 \\
\hline Arthritis & 14 & 46.66 \\
\hline Hematological involvement & 10 & 33.33 \\
\hline Renal involvement & 8 & 26.66 \\
\hline CNS involment & 3 & 10 \\
\hline Serositis & 2 & 6 \\
\hline
\end{tabular}

Table 3: Percentage $\mathrm{CD} 4^{+} \mathrm{T}$ cells, percentage $\mathrm{CD} 8^{+} \mathrm{T}$ cells, ratio $\mathrm{CD} 4^{+} / \mathrm{CD} 8^{+} \mathrm{T}$ cells and serum cortisol in patients with systemic lupus erythematosus (SLE) and the controls.

\begin{tabular}{|l|c|c|}
\hline & Controls & SLE Patients \\
\hline$\% \mathrm{CD}^{+} \mathrm{T}$ cells & $40.290 \pm 5.819$ & $27.084 \pm 6.002^{*}$ \\
\hline$\% \mathrm{CD}^{+} \mathrm{T}$ cells & $25.035 \pm 3.429$ & $36.179 \pm 6.495^{*}$ \\
\hline$\% \mathrm{CD}^{+} / \mathrm{CD}^{+} \mathrm{T}$ cell & $1.617 \pm 0.172$ & $0.755 \pm 0.124 *$ \\
\hline Cortisol $(\mathrm{mg} / \mathrm{dl})$ & $18.583 \pm 4.725$ & $11.183 \pm 4.742 *$ \\
\hline
\end{tabular}

Values are expressed as Mean $\pm \mathrm{SD}$

* Significantly different at $(P<0.001)$ 
Table 4: Correlation of T lymphocytes subset with SLE disease activity index (SLEDAI) score, complement protein (C4) and Erythrocyte sedimentation coefficient rate (ESR) in patients with systemic lupus erythematosus (SLE)

\begin{tabular}{|l|c|}
\hline Parameters & \multicolumn{1}{|c|}{ Spearman rank correlation coefficient (r) } \\
\hline $\mathrm{CD} 4^{+} \mathrm{T}$ cells with SLEDAI Score & $-0.3931^{*}$ \\
\hline $\mathrm{CD} 8^{+} \mathrm{T}$ cells with SLEDAI Score & $0.4748^{* *}$ \\
\hline $\mathrm{CD} 4^{+} / \mathrm{CD} 8^{+} \mathrm{T}$ cell with SLEDAI Score & $-0.5594^{* *}$ \\
\hline $\mathrm{CD} 8+\mathrm{T}$ cells with C4 protein & $-0.3631^{*}$ \\
\hline $\mathrm{CD} 8^{+} \mathrm{T}$ cells with ESR & $0.5926^{* * *}$ \\
\hline $\mathrm{CD} 4^{+} / \mathrm{CD} 8^{+} \mathrm{T}$ cell with ESR & $-0.4687^{* *}$ \\
\hline
\end{tabular}

Values are expressed as spearman coefficient (r).

* significantly different at $(P<0.05), * *(P<0.01)$ and *** $(P<0.001)$

a

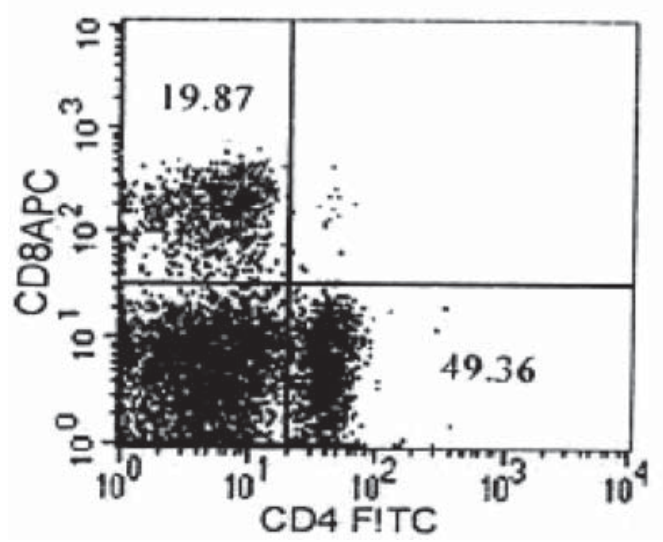

$\mathrm{b}$

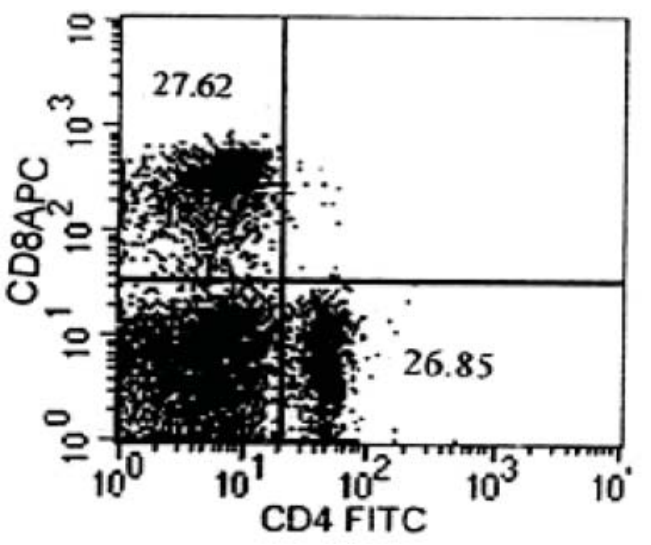

Fig 1: FACS analysis of percentage $C D 4^{+} \mathrm{T}$ cells and $\mathrm{CD} 8^{+} \mathrm{T}$ cells in the PMBC. The example shown is representative of 30 separate experiments. (a) a healthy control, (b) an SLE patient. Two colour staining protocol was used to assesses for the $\%$ expression of $\mathrm{CD}^{+}$and $\mathrm{CD} 8^{+} \mathrm{T}$ cells in the lymphocyte gate.

a

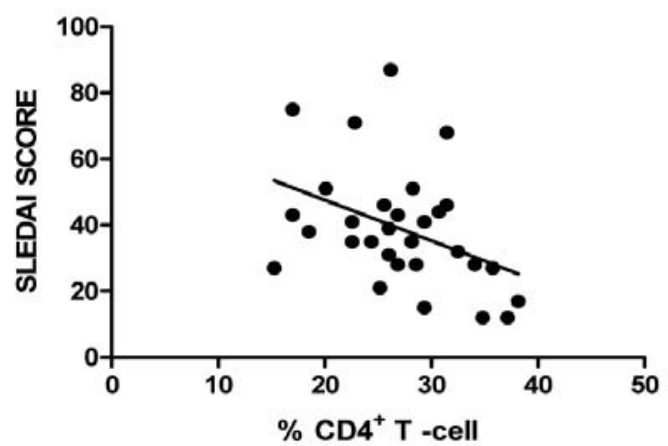

b

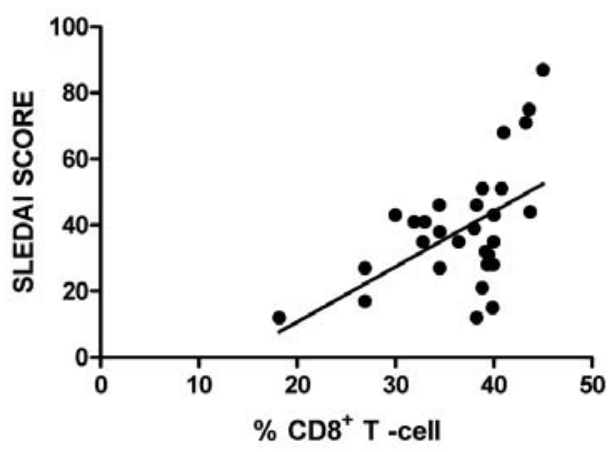


$\mathrm{C}$

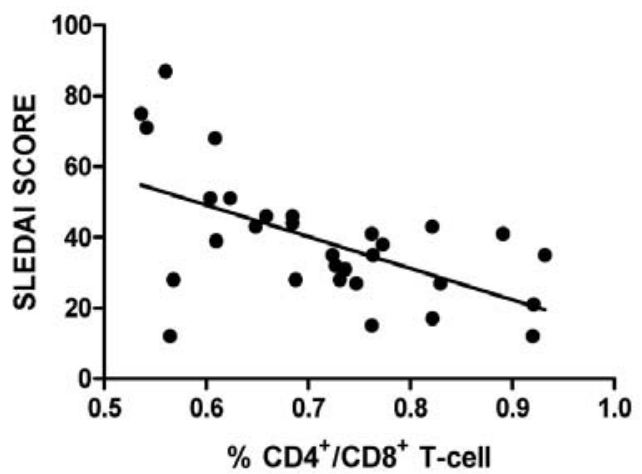

e

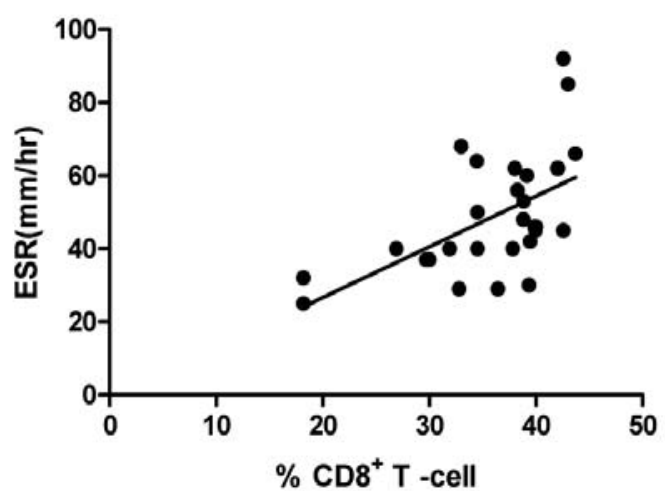

d

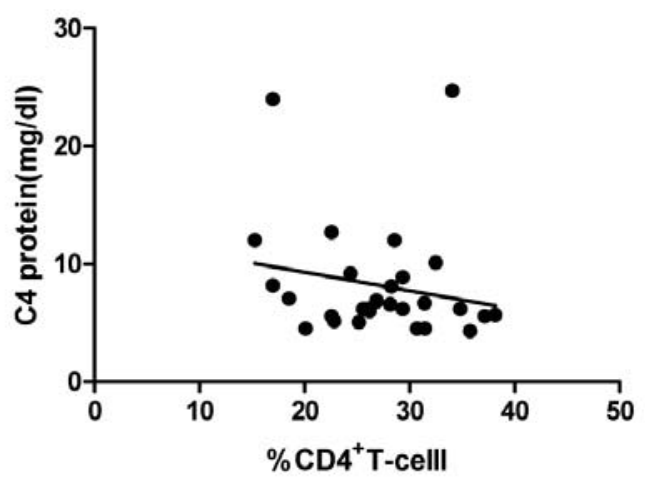

f

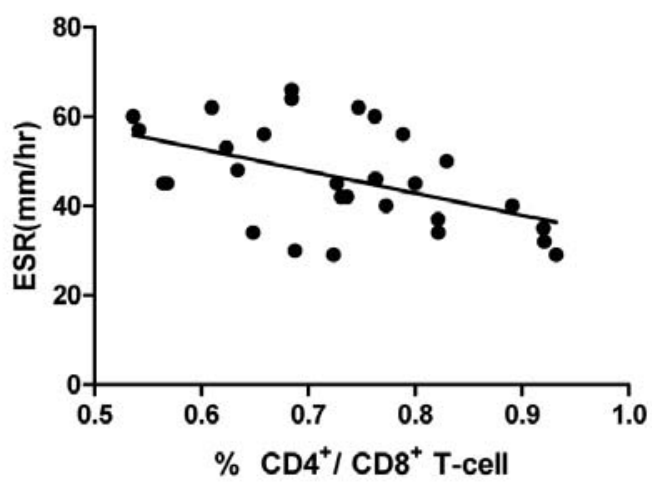

Fig 2: Correlations study between various parameters in the patients with SLE a) correlation between percentage of $\mathrm{CD}^{+} \mathrm{T}$ cells and systemic lupus erythematosus disease activity index (SLEDAI) score (Spearman's rank correlation coefficient $(\mathrm{r})=-0.3931, P<0.05) \mathrm{b}$ ) correlation between percentage of $\mathrm{CD} 8^{+} \mathrm{T}$ cells and SLEDAI score $(\mathrm{r}=0.4748, P<0.01) \mathrm{c})$ correlation between percentage of $\mathrm{CD} 4^{+} / \mathrm{CD} 8^{+} \mathrm{T}$ cell ratio and SLEDAI score $(\mathrm{r}=$ $0.4817, P<0.01) \mathrm{d})$ correlation between percentage of $\mathrm{CD} 8^{+} \mathrm{T}$ cells and $\mathrm{C} 4(\mathrm{r}=-0.3631, P<0.05)$ e) correlation between percentage of $\mathrm{CD}^{+} \mathrm{T}$ cells and $\left.\mathrm{ESR}(\mathrm{r}=0.5926, P<0.001) \mathrm{f}\right)$ correlation between percentage of $\mathrm{CD}^{+} /$ $\mathrm{CD} 8^{+} \mathrm{T}$ cell ratio and ESR $(\mathrm{r}=-0.4687, P<0.01)$.

\section{Discussion}

Systemic lupus erythematosus is a chronic inflammatory disease with unknown aetiology. Immunoregulatory abnormality is considered as one of the universal factors in the pathogenesis of SLE. The most common immunoregulatory abnormalities in SLE are deficiency in suppressor cell activity, hyperactive B cells, defective helper $\mathrm{T}$ cells, $\mathrm{CD} 4^{+} \mathrm{T}$ cells deficient in IL-2 production, impaired T-cell activation and responsiveness to antigens ${ }^{12,13,14}$. Different groups have reported variable results about $\mathrm{T}$ cells subsets in SLE patients. For example active SLE patients have been found with increased, decreased or normal $\mathrm{CD}^{+} \mathrm{T}$ cell count ${ }^{15,16}$. Abnormalities of $\mathrm{CD} 4^{+} \mathrm{T}$ cells may play an important role in the induction of $\mathrm{SLE}^{8}$. The most consistent finding in SLE is impairment of $\mathrm{CD}^{+} \mathrm{T}$ cell functions ${ }^{15,17}$. Studies have reported a relative reduction of $\mathrm{CD}^{+} \mathrm{T}$ cells and an increase in the ratio of $\mathrm{CD}^{+} /$
$\mathrm{CD}^{+} \mathrm{T}$ cell in patients with $\mathrm{SLE}^{18,19}$. However, other studies have found either a normal or an increased level of $\mathrm{CD}^{+} \mathrm{T}$ cells and a diminution of $\mathrm{CD} 4^{+} \mathrm{T}$ cells with a consequent decrease in the $\mathrm{CD} 4^{+} / \mathrm{CD}^{+} \mathrm{T}$ cell ratio in patients with active SLE. This was especially true in patients with severe lupus nephritis ${ }^{6,7}$. The present study showed, an increment in $\mathrm{CD} 8^{+} \mathrm{T}$ cell numbers and a decline in $\mathrm{CD}^{+} \mathrm{T}$ cells, with a consequent reduction in $\mathrm{CD}^{+} / \mathrm{CD}^{+} \mathrm{T}$ cell ratio in patients with SLE (Table 3). Similar result has been reported in SLE patients ${ }^{19,20}$. Mclnerney et $a l^{15}$ showed that $45 \%$ of the SLE patient population had markedly depressed CD4 T cell levels and significantly low CD4/CD8 $\mathrm{T}$ cell ratios while Matsushita et $a l^{20}$ showed an increase in $\mathrm{CD}^{+} \mathrm{T}$ cell population and decline in $\mathrm{CD}^{+} \mathrm{T}$ cell numbers in patients with SLE. Patients with decreased $\mathrm{CD} 4^{+} / \mathrm{CD}^{+}$ $\mathrm{T}$ cells ratio, had arthritis, rash and increased serological 
activation. Six of the patients with diminished $\mathrm{CD}^{+} /$ $\mathrm{CD}^{+} \mathrm{T}$ cell ratio had involvement of kidney (nephritis). Previous studies by Bakke et $a l^{5}$, Smolen et $a l^{6}$ and McInerney et $a l^{7}$ had similar results.

The $\mathrm{CD}^{+} \mathrm{T}$ cells were positively correlated with SLEDAI score and negatively correlated with C4 in the patients with SLE. An inverse correlation was obtained between $\mathrm{CD}^{+} / \mathrm{CD}^{+} \mathrm{T}$ cell ratio and SLEDAI score in patients with SLE. Additionally, $\mathrm{CD}^{+} / \mathrm{CD}^{+} \mathrm{T}$ cells ratio was also inversely correlated with ESR in SLE patients. No such correlations were found in healthy controls (data not shown). These results suggest that an activation of $\mathrm{T}$ cells strongly occurs in $\mathrm{CD}^{+} \mathrm{T}$ cells rather than $\mathrm{CD}^{+} \mathrm{T}$ cells. The actual cause for lowering of $\mathrm{CD}^{+} / \mathrm{CD}^{+} \mathrm{T}$ cell ratio in patients with SLE is still unclear. It is suggested that activated $\mathrm{CD}^{+} \mathrm{T}$ cells, and its derived interleukin (IL-16) promotes the activation and anergy of $\mathrm{CD}^{+} \mathrm{T}$ cells as well as their cell death, resulting in reduced $\mathrm{CD}^{+} / \mathrm{CD}^{+} \mathrm{T}$ cell ratio in SLE patients ${ }^{20}$. A negative correlation of $\mathrm{CD}^{+} / \mathrm{CD}^{+} \mathrm{T}$ cells ratio and a positive correlation of $\mathrm{CD} 8^{+} \mathrm{T}$ cells with SLEDAI score and ESR suggest that activated $\mathrm{CD}^{+} \mathrm{T}$ cells are involved in the pathogenesis of SLE. LinkerIsraeli et al. ${ }^{21,22}$ showed that the removal of HLA-DR+ $\mathrm{CD}^{+} \mathrm{T}$ cells and loss of the factors derived from $\mathrm{CD} 8^{+}$ $\mathrm{T}$ cells lead to the normalization of IL-2 production in the $\mathrm{CD}^{+} \mathrm{T}$ cells in SLE patients. This also supports the hypothesis that the activated $\mathrm{CD}^{+} \mathrm{T}$ cell is involved in the pathogenesis of SLE. The levels of complement proteins $\mathrm{C} 3$ and $\mathrm{C} 4$ concentration have also been found to be low in 16 patients with SLE which is similar to the study of Hussain et $a l^{23}$ A significant negative correlation was found between $\mathrm{CD}^{+} \mathrm{T}$ cells and $\mathrm{C} 4$ in the patients with SLE. This result suggests that activated $\mathrm{CD}^{+} \mathrm{T}$ cells may be involved in the alteration of complementary pathway in SLE patients.

The circulating lymphocyte has been markedly affected by corticosteroids in patients with $\mathrm{SLE}^{8,13}$. The low serum levels of cortisol is thought to have a proinflammatory role ${ }^{24}$ and proved to be a therapeutic alternative in $\mathrm{SLE}^{25}$. Zietz et $a l^{26}$ reported that serum cortisol is reduced relative to the degree of systemic inflammation in SLE and condition become severe when the disease persists over a long period of time (over weeks). In the present study, a significantly reduced level of cortisol was found in SLE patients compared to controls. This result is supported by the study of Straub et al. in SLE patients ${ }^{27}$. Straub et al demonstrated that low level of serum cortisol is not due to renal clearance in patients with SLE. Inadequate production of cortisol may be due to inflammation induced reduction of adrenal steroidogenesis ${ }^{28}$. Judd et $a l^{28}$ demonstrated in adrenocortical cells that proinflammatory cytokines such as a tumour necrosis factor (TNF) inhibit important enzyme steps of steroidogenesis. No significant correlation was found to exist between cortisol and $\mathrm{T}$ lymphocyte subsets in SLE patients and healthy controls. However, the correlation between cortisol and SLEDAI score was found to be negative, though not very significant in patients with SLE. This relation suggests that low level of cortisol may be involved in the disease activity in SLE.

\section{Conclusion}

The present study and those reported by other workers suggest that changes of T cell phenotype and $\mathrm{CD} 8^{+} \mathrm{T}$ cells activation may play an important role in the induction of autoimmunity in SLE. Altered T lymphocyte subsets and low cortisol affect clinical features of disease. Improvement of $\mathrm{CD}^{+} / \mathrm{CD}^{+} \mathrm{T}$ cell ratio may indicate control of disease, while abnormal $\mathrm{CD}^{+} / \mathrm{CD}^{+} \mathrm{T}$ cell ratio suggest deterioration or relapse in the clinical features of SLE.

\section{References}

1. Gordon C. Long-term complications of systemic lupus erythematosus. Rheumatology. 2002; 41: 1095-100.

2. Linker-israeli M, Quimorio FP, Horwitz DA. $\mathrm{CD}^{+}$lymphocytes from patients with systemic lupus erythematosus sustain, rather than suppress, spontaneous polyclonal $\mathrm{IgG}$ production and synergize with $\mathrm{CD}^{+}$cells to support autoantibody synthesis. Arthritis Rhem. 1990; 33:1216-25.

3. Horowitz DA, Stohl W, Gray JD. T lymphocytes, natural killer cells, cytokines, and immune regulation. In Wallance DJ, Harn BH (editors). Dubois lupus erythematosus. Baltimore: Williams \& Wilkin; 1997.p. 155-94.

4. Maeda N, Sekigawa I, lida N, Matsumoto M, Hashimoto H, Hirose S. Relationship between $\mathrm{CD}^{+} / \mathrm{CD}^{+} \mathrm{T}$ cell ratio and $\mathrm{T}$ cell activation in systemic lupus erythematosus. Scand J Rheumntol. 1999; 29: 166-70.

5. BakkeAC, Kirkland PA, Kitridou RC, Quismorio FP, Rea T, Ehresmann GR. T lymphocyte subsets in systemic lupus erythematosus. Arthritis Rheum. 1983; 26:745-50.

6. Smolen JS, Chused TM, Leiserson WN, Reeves JP, Alling D, Steinberg AD. Heterogeneity of immunoregulatory T-cell subsets in systemic lupus erythematosus. Am J Med. 1982;72:78390.

7. McInerney MF, Clough JD, Seniztzer D, Cathcart MK. Two distinct subsets of patients with systemic lupus erythematosus. Clin Immunol Immunopathol. 1988; 49:116-32. 
8. Raziuddin S, Nur MA, Al-Wabel AA. Increased circulating $\mathrm{HLA}-\mathrm{DR}^{+} \mathrm{CD} 4^{+} \mathrm{T}$ cell in systemic lupus erythematosus: Alterations associated with prednisolone therapy. Scand J Immunol. 1990; 31:139-45.

9. Zietz B, Reber T, Oertel M, Glück T, Scho lmerich J, Straub RH. Altered function of the hypothalamic stress axes in patients with moderately active systemic lupus erythematosus. II. Dissociation between androstenedione, cortisol, or dehydroepiandrosterone and interleukin 6 or tumor necrosis factor. J Rheumatol. 2000; 27: 911-18.

10. Tan EM, Cohen AS, Fries JF, Masi AT, McShane DJ, Rothfield NF, et al. The 1982 revised criteria for the classification of systemic lupus erythematosus. Arthritis Rheum. 1982; 25:1271-7

11. Bombardier C, Gladman DD, Urowitz MB, Caron D, Chang CH, Derivation of the SLEDAI. A disease activity index for lupus patients. The Committee on Prognosis Studies in SLE. Arthritis Rheum. 1992; 35: 630-40.

12. Cohen PL. T and B cell abnormalities in systemic lupus. J Invest Dermatol. 1993; 100: 69S-72S.

13. Kammer GM, Stein RL. T lymphocyte immune dysfunction in systemic lupus erythematosus. J Lab Clin Med. 1990; 115: 273-82.

14. Fauci A, Steinberg A, Haynes B, Whalen G. Immunoregulatory aberrations in systemic lupus erythematosus. J Immunol. 1978; 121:1473-9.

15. Raziuddin S, Nur MA, Alwabel AA. Selective loss of the CD $4+$ inducers of suppresser $\mathrm{T}$ cell subsets $(2 \mathrm{H} 4+)$ in active systemic lupus erythematosus. J Rheumatol. 1989; 16:1315-9.

16. Yang JL, Chen PZ, Dong Y, Tang FL, Zhang NZ. A preliminary study on $\mathrm{T}$ lymphocyte subsets in systemic lupus erythematosus. Chin Med J (Engl). 1988; 101: 665-70.

17. Lipnick RN, Balow JE, Tsokos GJ. Lymphocyte subpopulation in patient with systemic lupus erythematosus. Clin Immunol Immunopathol. 1984; 31:181-90.

18. Morimoto C, Reinherz EL, Schlossman SF, Schur PH, Mills JA, Steinberg AD. Alteration in $\mathrm{T}$ cell subsets in active systemic lupus erythematosus. J Clin Invest. 1980; 66:1171 -4.

19. Tsokos GC, Balow JE. Phenotypes of T lymphocytes in systemic lupus erythematosus: decreased cytotoxic/suppressor subpopulation is associated with deccient allogenic cytotoxic responses rather than with concanavalin A-induced suppressor cells. Clin Immunol Immunopathol. 1983; 26:262-76.

20. Matsushita M, Hayashi T, Ando S, Sekigawa I, Iida N, Hashimoto H, et al. Changes of CD4/ CD8 Ratio and Interleukin-16 in Systemic Lupus Erythematosus. Clin Rheumatol. 2000; 19:270-4.

21. Linker-Israeli M, Gray JD, Quismorio FP Jr, Horwitz DA. Correlation of interleukin-2 production in patients with systemic lupus erythematosus by removal of spontaneously activated suppressor cells. J Clin Invest. 1995; 75:762-8.

22. Linker-Israeli M, Casteel N. Partial purification of systemic lupus erythematosus-derived factors that suppress production of interleukin-2. J Rheumatol. 1988; 15:952-8.

23. Hussain N, Jaffery G, Hasnain S. Serum complement $\mathrm{C} 3$ and $\mathrm{C} 4$ levels in relation to diagnosis of lupus nephritis. Trop J Pharm Res. 2008; 7: 1117-21.

24. Petri MA, Lahita RG, van Vollenhoven RF, Merrill JT, Schiff M, Ginzler EM, et al. Effects of prasterone on corticosteroid requirements of women with systemic lupus erythematosus: a double-blind, randomized, placebocontrolled trial. Arthritis Rheum. 2002; 46:1820-9.

25. Straub RH, Cutolo M. Involvement of the hypothalamic-pituitary-adrenal/ gonadal axis and the peripheral nervous system in rheumatoid arthritis: viewpoint based on a systemic pathogenetic role. Arthritis Rheum. 2001; 44:493-507.

26. Zietz B, Reber T, Oertel M, Glück T, Scho"lmerich J, Straub RH. Altered function of the hypothalamic stress axes in patients with moderately active systemic lupus erythematosus. II. Dissociation between androstenedione, cortisol, or dehydroepiandrosterone and interleukin 6 or tumor necrosis factor. J Rheumatol. 2000; 27:911-8.

27. Straub RH, Weidler C, Demmel B, Herrmann M, Kees F, Schmidt M, et al. Renal clearance and daily excretion of cortisol and adrenal androgens in patients with rheumatoid arthritis and systemic lupus erythematosus. Ann Rheum Dis. 2004; 63:961-68.

28. Judd AM, Call GB, Barney M, McIlmoil CJ, Balls AG, Adams A, et al. Possible function of IL- 6 and TNF as intraadrenal factors in the regulation of adrenal steroid secretion. Ann N Y Acad Sci. 2000; 917:628-37. 